mediate, and $21.3 \%$ terminal. According to the chronic cases, $41 \%$ showed initial insomnia, $40 \%$ intermediate, and $19 \%$ terminal.

Insomnia was more associated with female sex, divorced and widows, the lowest income classes $D / E$, low educational degree, and less associated with younger age group (18-30 years old). Sleep-promoting medication was used by $48 \%$ of the insomni- acs; only $17.5 \%$ of them visited a physician with the purpose to complain insomnia.

Our findings showed that the insomnia prevalence in the adult population of São Jose do Rio Preto may be compared with the population of North American and European countries as well as other Brazilian cities.

KEY WORDS: insomnia, epidemiology, prevalence.

* Características clínicas e demográficas da insônia na população adulta urbana de São José do Rio Preto (Resumo). Tese de Doutorado. Faculdade de Medicina de São José do Rio Preto (Área Medicina Interna). Orientador: Waldir Antonio Tognola; Co-Orientador: Rubens Reimão.

**Address: Avenida Brigadeiro Faria Lima 5416 15090-000 São José do Rio Preto SP, Brazil.

\title{
CHARACTERIZATION OF TAENIA CRASSICEPS CYSTICERCI AND THEIR APPLICATION TO DIAGNOSIS OF THE HUMAN CYSTICERCOSIS (ABSTRACT)*. THESIS. SÃO PAULO, 2004.
}

\section{NOELI MARIA ESPÍNDOLA**}

Taenia crassiceps cysticerci were kept in vitro during 144h. Excretory/secretory (ES) antigens (peptides of $<30 \mathrm{kDa}$ ) were identified in 24 (ES24) and $48 \mathrm{~h}$ (ES48). ES peptides (30-, 18- and 14-12-kDa) were recognized by polyclonal antibodies in sera from rabbits immunized with Taenia crassiceps (Tcra) and Taenia solium (Tso) antigens, and also by antibodies in samples of serum and cerebrospinal fluid (CSF) from patients with neurocysticercosis (NC).

Monoclonal antibodies (MoAb) were prepared against ES-Tcra, Tcra vesicular fluid (VF-Tcra), Tso vesicular fluid (VF-Tso), Tso total (T-Tso) and scolex (E-Tso) antigens.

Twenty-four MoAb were obtained and they were used for the characterization of Tcra and Tso antigens, and for the antigen detection in samples of patients with NC. Nine MoAb (1 anti-ES-Tra, 1 anti-VF-Tcra, 3 anti-VF-Tso and 4 anti-T-Tso) reacted with peptides in the Tcra (18- and 14-12-kDa) Tso (14-12kDa) antigens. These low-molecular- weight peptides have been considered the immunodominant and specific antigen for the diagnosis of NC.

The MoAb maintained their reactivity towards VF-Tcra antigen treated with heat and alkaline borohydride and showed reduction after trichloroacetic acid and periodate oxidation treatments. These results indicate that the 18- and $14-12-k D a$ fractions are glycoproteins.

Peptides of $<20 \mathrm{kDa}$ in VF-Tcra antigen were purified by anti-Tcra MoAb and were used to detect antibodies in serum and CSF from patients with NC. Anti-Tcra and anti-Tso MoAb were used to detect antibodies by a competitive assay, and anti-Tcra MoAb to detect antigens in serum and CSF from patients with NC. The results showed a better performance than the use of brute antigens or polyclonal antibodies.

KEY WORDS: Taenia crassiceps antigens, neurocysticercosis diagnosis, cerebrospinal fluid.

*Caracterização de antígenos de cisticercos e sua aplicação para o diagnóstico da cisticercose humana (Rsumo). Tese (Doutorado), Universidade de São Paulo (Área: Análises clínicas). Orientador: Adelaide José Vaz.

**Adress: Departamento de Análises Clínicas e Toxicológicas da Faculdade de Ciências Farmaceuticas da USP. Avenida Prof. Lineu Pretes 580 bloco 17, 05508-900 São Paulo SP, Brasil. E-mail: ajvaz@usp.br

INTRASELLAR PRESSURE IN PITUITARY TUMORS. RELATION STUDY: INTRASELLAR PRESSURE vs HYPOTHALAMIC - PITUITARY FUNCTION. (ABSTRACT)*. DISSERTATION. SÃO PAULO, 2004.

\section{JACKSON AUGUSTO GONDIM OLIVEIRA**}

Between August 2002 and May 2003, 30 patients with pituitary adenomas had their intrasellar (tu- moral) pressure measured during transsphenoidal endoscopic surgery for these tumors. The age var- 